\title{
Assessing net community production in a glaciated Alaskan fjord
}

\author{
S. C. Reisdorph ${ }^{1}$ and J. T. Mathis ${ }^{2}$ \\ ${ }^{1}$ University of Alaska Fairbanks, Ocean Acidification Research Center, Fairbanks, USA \\ ${ }^{2}$ NOAA - Pacific Marine Environmental Laboratory, Seattle, USA \\ Correspondence to: S. C. Reisdorph (screisdorph@alaska.edu) \\ Received: 6 August 2014 - Published in Biogeosciences Discuss.: 9 September 2014 \\ Revised: 29 June 2015 - Accepted: 17 July 2015 - Published: 3 September 2015
}

\begin{abstract}
The impact of deglaciation in Glacier Bay has been observed to seasonally influence the biogeochemistry of this marine system. The influence from surrounding glaciers, particularly tidewater glaciers, has the potential to affect the efficiency and structure of the marine food web within Glacier Bay. To assess the magnitude and the spatial and temporal variability in net community production in a glaciated fjord, we measured dissolved inorganic carbon, inorganic macronutrients, dissolved oxygen, and particulate organic carbon between July 2011 and July 2012 in Glacier Bay, Alaska. High net community production rates were observed across the bay $\left(\sim 54\right.$ to $\sim 81 \mathrm{mmol} \mathrm{C} \mathrm{m}^{-2} \mathrm{~d}^{-1}$ ) between the summer and fall of 2011. However, between the fall and winter, as well as between the winter and spring of 2012, air-sea fluxes of carbon dioxide and organic matter respiration made net community production rates negative across most of the bay as inorganic carbon and macronutrient concentrations returned to pre-bloom levels. The highest organic carbon production occurred within the west arm between the summer and fall of 2011 with $\sim 4.5 \times 10^{5} \mathrm{~kg} \mathrm{C} \mathrm{d}^{-1}$. Bay-wide, there was carbon production of $\sim 9.2 \times 10^{5} \mathrm{~g} \mathrm{Cd}^{-1}$ between the summer and fall. Respiration and air-sea gas exchange were the dominant drivers of carbon chemistry between the fall and winter of 2012. The substantial spatial and temporal variability in our net community production estimates may reflect glacial influences within the bay, as meltwater is depleted in macronutrients relative to marine waters entering from the Gulf of Alaska in the middle and lower parts of the bay. Further glacial retreat will likely lead to additional modifications in the carbon biogeochemistry of Glacier Bay, with unknown consequences for the local marine food web, which includes many species of marine mammals.
\end{abstract}

\section{Introduction}

Glacier Bay lies within the Gulf of Alaska coastal ocean and is a pristine glacially influenced fjord that is representative of many other estuarine systems that border the Gulf of Alaska (Fig. 1). Glacier Bay is influenced by freshwater input, primarily from many surrounding alpine and tidewater glaciers. The low-nutrient influx of freshwater into Glacier Bay, which is highest (up to $\sim 40 \%$ freshwater in surface waters during the summer; Reisdorph and Mathis, 2014) along the northern regions of the bay, affects the nutrient loading and thus biological production and carbon dioxide $\left(\mathrm{CO}_{2}\right)$ fluxes within the bay. The southern region of the bay is less affected by this runoff due to distance from the glacial influence and is more influenced by marine waters that exchange through a narrow channel with a shallow entrance sill $(\sim 25 \mathrm{~m})$.

Over the past $\sim 250$ years, Glacier Bay has experienced very rapid deglaciation, which has likely impacted the biological structure of the bay. As the climate continues to warm, additional changes to this ecosystem and marine population have the potential to impact net community production (NCP) within the bay, with cascading effects through the food web. To better understand the seasonal dynamics of the underlying biogeochemistry in Glacier Bay, we used the seasonal drawdown of the inorganic constituents of photosynthesis within the mixed layer to estimate regional mass flux of carbon and rates of NCP along with air-sea flux rates of $\mathrm{CO}_{2}$. This approach has been used in other high-latitude regions to assess ecosystem functionality (e.g., Mathis et al., 2009; Cross et al, 2012; Mathis and Questel, 2013), including NCP and carbon cycling.

Previous studies have shown there is wide-ranging variability in rates of primary production within other glaciated fjord systems, though NCP data within these ecosystems 


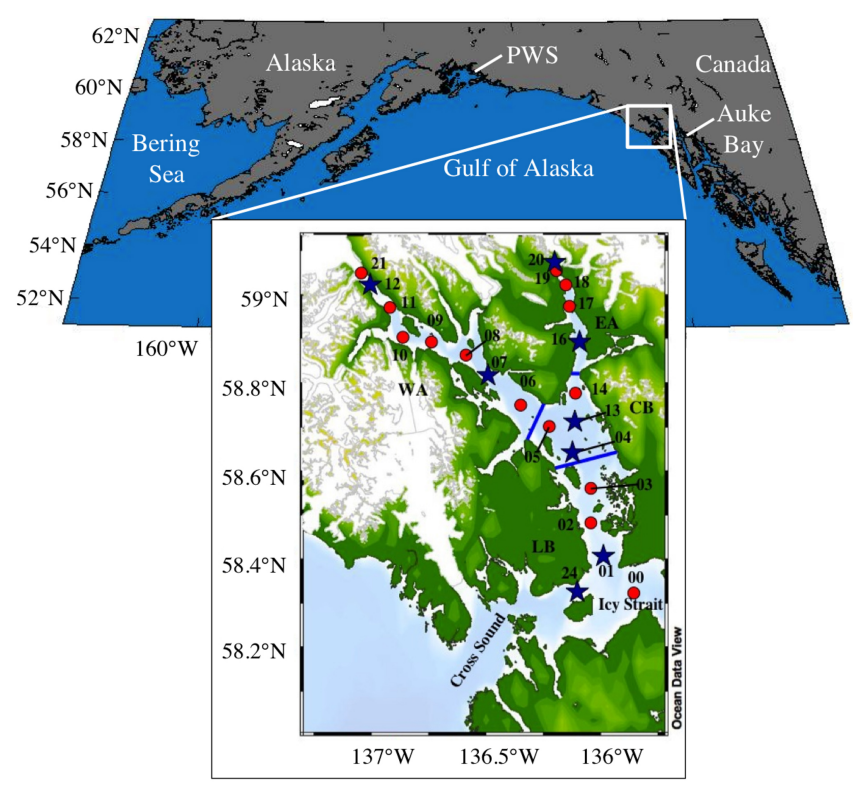

Figure 1. Glacier Bay location and oceanographic sampling station map. Blue lines denote regional boundaries between lower bay, central bay, east arm, and west arm. Red dots show all oceanographic station locations with station number. Blue stars represent "core" station locations.

are sparse. Fjords within the central Patagonia region (48$51^{\circ} \mathrm{S}$ ) are strongly influenced by glaciated terrain and freshwater runoff, similar to influences in and around Glacier Bay. A study by Aracena et al. (2011) looked at water column productivity in response to surface sediment export production in various Chilean Patagonia fjords $\left(41-56^{\circ} \mathrm{S}\right)$. They calculated primary production rates during the summer between $\sim 35 \mathrm{mmol} \mathrm{C} \mathrm{m}^{-2} \mathrm{~d}^{-1}$ in the more southern regions $\left(52-55^{\circ} \mathrm{S}\right)$ and $\sim 488 \mathrm{C} \mathrm{m}^{-2} \mathrm{~d}^{-1}$ to the north $\left(41-\sim 44^{\circ} \mathrm{S}\right)$. In central Patagonia, Aracena et al. (2011) estimated primary productivity at $\sim 57 \mathrm{mmol} \mathrm{C} \mathrm{m}^{-2} \mathrm{~d}^{-1}$ in the spring, a value comparable to some seasonal estimates in Glacier Bay, and found primary production rates comparable to those of Norwegian fjords $\left(\sim 9\right.$ to $\left.\sim 360 \mathrm{mmol} \mathrm{C} \mathrm{m}^{-2} \mathrm{~d}^{-1}\right)$.

There have been a number of studies conducted within Glacier Bay, though conclusions of several studies are contradictory. Many of these studies had a short duration and limited coverage, missing much of the spatial, seasonal, and annual variability (Hooge et al, 2003). This lack of data leads to a significant gap in understanding of carbon cycling in Glacier Bay, as well as a lack of predictability of responses to changes in this estuarine system as climate change progresses. To capture some of the seasonal and spatial variability in the bay, we collected and analyzed monthly samples over a 2-year period. This sampling regime, along with the variety of samples taken, has provided us with the most robust data set collected in Glacier Bay and allowed us to elucidate the dynamic nature of NCP in a glaciated fjord. Our goal for this study was to estimate the current level of seasonal
NCP in Glacier Bay and evaluate how this, along with airsea $\mathrm{CO}_{2}$ flux, impacts the carbon dynamics in this glaciated fjord. Our findings also contribute to the limited knowledge regarding carbon cycling in Glacier Bay and how it is impacted by glacial runoff. Our estimates are the first attempt to assess the impact of seasonal glacial melt on NCP in Glacier Bay. We wish to fill in some gaps in how glacial freshwater may influence NCP within a glaciated fjord ecosystem and estimate how continued glacial melt may impact productivity in Glacier Bay.

\section{Background}

Glacier Bay was once covered by one large icefield, the Glacier Bay Icefield; since the Industrial Revolution the icefield has been rapidly retreating, scouring the bay and leaving behind many alpine and tidewater glaciers. Currently, the marine portion of Glacier Bay is roughly $100 \mathrm{~km}$ from the entrance sill to the end of the west arm, and reaches depths $>400$ and $>300 \mathrm{~m}$ in the east arm and west arm, respectively (Fig. 2).

Seasonal variation in factors such as light availability, turbulent or wind mixing, and freshwater input impact physical conditions that are vital to primary production, including stratification, photic depth, and nutrient availability. These drivers of NCP vary temporally and spatially within Glacier Bay. Glacial runoff, along with glacial stream input, imparts freshwater into the marine system, especially along the arms of the bay. Peak runoff has been shown to occur during the fall, though there is fairly constant flow from June to September (Hill et al., 2009). Low-nutrient glacial runoff is prevalent, and while it aids in stratification, its low macronutrient concentrations dilute available nutrients in the northern regions nearest tidewater outflows. In the lower parts of the bay, glacial influence is lower and macronutrients are more abundant, allowing higher levels of primary production during spring and summer. Glacier Bay maintains relatively elevated phytoplankton concentrations throughout the year compared to levels observed in similar Alaskan fjords (Hooge and Hooge, 2002). However, insufficient research has been done on the biological system within Glacier Bay to understand why this occurs.

For this paper, we have calculated seasonal NCP and airsea carbon flux for the four regions within Glacier Bay in order to better understand ecosystem production in a glacially dominated environment, representative of much of the southern coastal Alaska region. This study has greatly enhanced our understanding of how glacial melt and air-sea flux impacts dissolved inorganic carbon (DIC) concentrations and NCP in estuaries, like Glacier Bay, which are numerous along the Gulf of Alaska coast in Alaska and worldwide. 


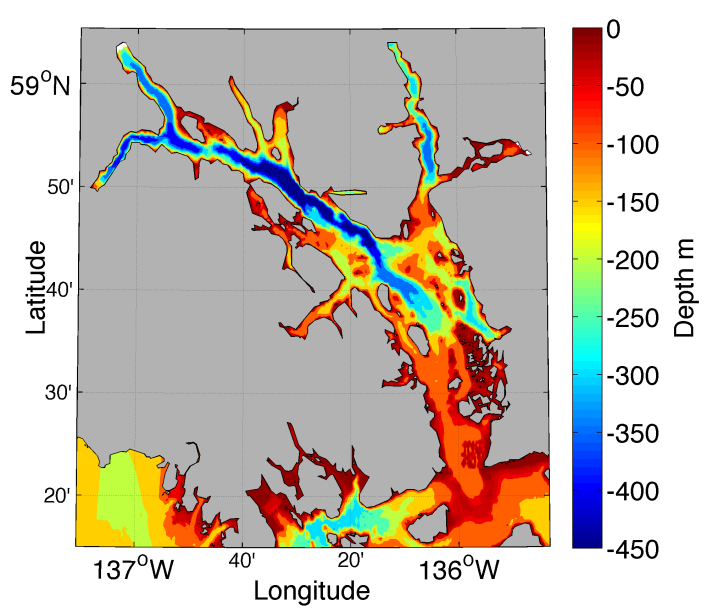

Figure 2. Bathymetric map of Glacier Bay.

\section{Methods}

Ten oceanographic cruises took place aboard the National Park Service's R/V Fog Lark between July 2011 and July 2012. Water column samples were collected at six depths $(2,10,30,50,100 \mathrm{~m}$, and near the bottom) at each station throughout the bay (Fig. 1) with a maximum depth within the west arm of $\sim 430 \mathrm{~m}$ (Fig. 2). Sampling depths correspond with those currently being used by the Glacier Bay long-term monitoring program and determined by the USGS in the 1990s. Each "core" station (Fig. 1) was sampled during every oceanographic sampling cruise, while all 22 stations were sampled during the months of July and January. "Surface" water refers to water collected from a depth of $2 \mathrm{~m}$ unless otherwise stated. Seasonal data were calculated by averaging each measured parameter at each depth for all cruises during the respective seasons. The summer season consists of June, July, and August; fall includes September and October; winter is comprised of February and March cruises; and the spring season includes the months of April and May. Data have been averaged regionally within each of the four regions of the bay (lower bay, central bay, east arm, and west arm; Fig. 1). Regional boundaries were selected based on historical and ongoing research in Glacier Bay. Bathymetry data (Fig. 2) were retrieved from the National Geophysical Data Center.

Conductivity, temperature and pressure were collected on downcasts with a Sea-Bird 19plus CTD. Dissolved oxygen (referred to simply as "oxygen" hereafter) was sampled and processed first to avoid compromising the samples by atmospheric gas exchange. Samples for oxygen analysis were drawn into individual $115 \mathrm{~mL}$ biological oxygen demand flasks and rinsed with 4-5 volumes of sample, treated with $1 \mathrm{~mL} \mathrm{MnCl}_{2}$ and $1 \mathrm{~mL} \mathrm{NaI} / \mathrm{NaOH}$, plugged, and the neck filled with DI water to avoid atmospheric exchange. Dissolved oxygen was sampled and analyzed using the Winkler titrations and the methods of Langdon (2010). Sam- ples were analyzed within $48 \mathrm{~h}$. Apparent oxygen utilization (AOU) was derived from observed oxygen concentrations using Ocean Data View calculations in version 4.6.2 (Schlitzer, 2013).

DIC and total alkalinity (referred to as "alkalinity" hereafter) samples were drawn into $250 \mathrm{~mL}$ borosilicate bottles. Samples were fixed with a saturated mercuric chloride solution $(200 \mu \mathrm{L})$, the bottles sealed, and stored until analysis at the Ocean Acidification Research Center at the University of Alaska Fairbanks. High-quality DIC data were attained by using a highly precise $\left(0.02 \% ; 0.4 \mu \mathrm{mol} \mathrm{kg}{ }^{-1}\right)$ VINDTA $3 \mathrm{C}$ coulometer system. Alkalinity was determined by potentiometric titration with a precision of $\sim 1 \mu \mathrm{mol} \mathrm{kg}{ }^{-1}$. Certified reference material, prepared and distributed by Scripps Institute of Oceanography, University of California, San Diego (Dr. Andrew Dickson's Laboratory), was run daily before sample analysis to ensure accuracy of sample values. The VINDTA 3C provides real-time corrections to DIC and alkalinity values according to in situ temperature and salinity.

Dissolved macronutrient samples (nitrate, phosphate, silicate) were filtered through $0.8 \mu \mathrm{m}$ Nuclepore filters using in-line polycarbonate filter holders into $25 \mathrm{~mL}$ HDPE bottles and frozen $\left(-20^{\circ} \mathrm{C}\right)$ until analysis at the University of Alaska Fairbanks (UAF). Samples were filtered to remove any particles, such as glacial silt, that had the potential to clog equipment during analysis. Samples were analyzed within several weeks of collection using an Alpkem Rapid Flow Analyzer 300 and following the protocols of Mordy et al. (2010).

Particulate organic carbon (POC) samples were collected from Niskin bottles into brown $1 \mathrm{~L}$ Nalgene bottles and stored for filtering within 2 days of collection. Samples were collected at $2 \mathrm{~m}, 50 \mathrm{~m}$, and bottom depths. A known volume of samples was filtered through muffled and preweighed $13 \mathrm{~mm}$ type $\mathrm{A} / \mathrm{E}$ glass fiber filters using a vacuum pump. Muffling involved using tweezers to wrap filters in aluminum foil and heating them at $450^{\circ} \mathrm{F}$ for $\sim 6 \mathrm{~h}$ in a muffling furnace in order to remove any residual organic material. Filtered samples were frozen for transport back to UAF, where they were then dried and reweighed. Analyses were completed by OARC (Ocean Acidification Research Center) at UAF and were run using the methods outlined in Goñi et al. (2003).

The partial pressure of $\mathrm{CO}_{2}\left(p \mathrm{CO}_{2}\right)$ was calculated using CO2SYS (version 2.0), a program that employs thermodynamic models of Lewis and Wallace (1998)to calculate marine carbonate system parameters. Seasonally averaged atmospheric $p \mathrm{CO}_{2}$ values ( $\mu$ atm) were used $(388.4,388.9$, 393.4, 393.8, and 391.8) for summer 2011 through summer 2012 , respectively, and were averaged from the monthly averaged Mauna Loa archive found at www.esrl.noaa.gov. For seawater $p \mathrm{CO}_{2}$ calculations in CO2SYS, we used $K_{1}$ and $K_{2}$ constants from Mehrbach et al. (1973) and refit by Dickson and Millero (1987), $\mathrm{KHSO}_{2}$ values from Dickson, the seawater $\mathrm{pH}$ scale, and the $[\mathrm{B}]_{T}$ value from Uppström (1974). 
$\mathrm{CO}_{2}$ fluxes were calculated using seasonally averaged seawater temperature, wind speed, and seawater and atmospheric $p \mathrm{CO}_{2}$ data using the equation

Flux $=L \cdot\left(\Delta p \mathrm{CO}_{2}\right) \cdot k$,

where $L$ is the solubility of $\mathrm{CO}_{2}$ at a specified seawater temperature in $\mathrm{mmol} \mathrm{m}^{-3} \mathrm{~atm}^{-1}$ and $\Delta p \mathrm{CO}_{2}$ represents the difference between seawater and atmospheric $p \mathrm{CO}_{2}$ in $\mu \mathrm{atm} . k$ is the steady/short-term wind parameterization in $\mathrm{cm} \mathrm{h}^{-1}$ at a specified wind speed and follows the equation

$k=0.0283 \cdot U \cdot(S c / 660)^{(1 / 2)}$,

where $U$ is wind speed in $\mathrm{m} \mathrm{s}^{-1}$ and $S c$ is the Schmidt number (kinematic velocity of the water divided by the molecular diffusivity of a gas in water). The $S c$ was normalized to $660 \mathrm{~cm} \mathrm{~h}^{-1}$ and is equivalent to the $S c$ for $\mathrm{CO}_{2}$ in $20^{\circ} \mathrm{C}$ seawater (Wanninkhof and McGillis, 1999). Wind speeds were cubed using the methods of Wanninkhof and McGillis (1999) in an attempt to account for the retardation of gas transfer at low to moderate wind speeds by surfactants and the bubbleenhanced gas transfer that occurs at higher wind speeds.

Seawater temperatures for flux calculations were taken from surface bottle CTD data. Wind speeds were obtained from a Bartlett Cove, Alaska, weather station (station BLTA2) located in Glacier Bay and maintained by the National Weather Service Alaska Region.

$\mathrm{NCP}$ calculations were made using the seasonal drawdown of photosynthetic reactant DIC within the mixed layer (upper $30 \mathrm{~m}$ ) and were normalized to a salinity of 35 . NCP was calculated between each season from the summer of 2011 to the summer of 2012 (i.e., the change in concentrations between each consecutive season) according to the equation (Williams, 1993),

$\mathrm{NCP}=\mathrm{DIC}_{\text {spring }}-\mathrm{DIC}_{\text {summer }}$

$=\Delta \mathrm{DIC}($ moles $\mathrm{C}$ per unit volume area $)$.

The influx of high-DIC waters (e.g., river discharge) can cause a dampening of the NCP signal. This effect can be accounted for by normalizing DIC to a constant deep-water reference salinity ( $S=35$; Millero et al., 2008). Since this equation only reflects the effects of DIC, freshwater influences on alkalinity were accounted for by correction of the seasonal changes in alkalinity (Lee, 2001) using the equation

$\Delta \mathrm{DIC}_{\mathrm{Alk}}=0.5 \cdot\left(\Delta \mathrm{Alk}+\Delta \mathrm{NO}_{3}\right)$

and subtracting this value from the seasonal change in salinity-normalized DIC (nDIC), thus providing an NCP in which the significant process influencing seasonal changes to DIC concentrations is biological productivity (Bates et al, 2005; Mathis et al., 2009; Cross et al., 2012). Error imparted in calculating parameters, including DIC analysis and averaging of nutrient concentrations within the mixed layer, is propagated through our NCP estimates at $\sim \pm 5 \%$ of the final NCP calculation. Error propagated through each NCP estimate is listed with the NCP calculations in Table 1.

\section{Caveats}

While seasonal water column DIC concentration changes can be a good approximation to determine seasonal NCP, there are several estuarine processes that we were unable to constrain that likely influenced our NCP estimates and act as additional sources of uncertainty. Some other sources of uncertainty, such as the influence of glacial flour, were reduced through averaging of spatial and regional parameters as stations were reoccupied within $\sim 30$ days of one another.

Glacial flour can enhance DIC concentrations in seawater. Therefore, there is the possibility that the inclusion of glacial flour may have increased our DIC concentrations with respect to DIC drawdown from primary production. In this case, our estimates may underestimate NCP. However, we were not able to quantify the amount of glacial flour deposited in Glacier Bay or analyze its composition for this study. In Glacier Bay, the influence of glacial flour is limited to the northern regions (i.e., east and west arms) that are directly influence by glacial outflow, many of which enter the bay along inlets and not the main arms of the bay, possibly reducing the impact of glacial flour at many stations. Unfortunately, there are insufficient data to quantitatively estimate the amount and makeup of glacial flour or what error it imparts into our NCP calculations, but we assume for the sake of our analysis that it is relatively small.

Freshwater runoff that enters the bay via glacial streams flows over streambeds and can leach minerals and nutrients from bedrock, enhancing these concentrations in the surface waters of Glacier Bay. While stream water runoff in Glacier Bay was not analyzed for this study, studies of glacial runoff in southeast Alaska have shown allochthonous stream water dissolved organic carbon (DOC) to be negatively correlated with glacial coverage (Hood et al., 2009). Examining watersheds along the Gulf of Alaska, Hood et al. (2009) also found that the most heavily glaciated watersheds were a source of the oldest, most labile (66\% bioavailable) dissolved organic matter (DOM) and that increased input of glacial melt was associated with increased proportions of DOM from microbial sources. As we were unable to chemically analyze glacial runoff in Glacier Bay, our NCP calculations using only changes in DIC concentrations underestimate NCP in the bay, though freshwater input is corrected to some degree by salinity-normalized DIC concentrations. The quantification of freshwater input into the bay is also hindered by the lack of any active gauging stations within the bay (Hill et al., 2009). Glacially derived DOC has been shown to be highly bioavailable, though inversely correlated with glacial coverage (Hood et al., 2009, 2015). While the remineralization of highly labile DOC between station occupations could have added DIC back into mixed layer and decreased the signal of seasonal drawdown, any significant contribution of DIC from remineralization in the mixed layer seems unlikely given the slow remineralization rates and the short time periods $(\sim 30$ days) between station occupations. 
Table 1. Regional rates and masses of NCP - NCP by region in Glacier Bay based the change in salinity-normalized DIC concentrations between seasons.

\begin{tabular}{|c|c|c|c|c|}
\hline Seasonal transition & Region & $\begin{array}{l}\text { Regional area } \\
\qquad\left(\mathrm{m}^{2}\right)\end{array}$ & $\begin{array}{r}\text { NCP rate } \\
\left(\mathrm{mmol} \mathrm{C} \mathrm{m}^{-2} \mathrm{~d}^{-1}\right)\end{array}$ & $\begin{array}{l}\text { NCP mass } \\
\left(\mathrm{kg} \mathrm{C} \mathrm{d}^{-1}\right)\end{array}$ \\
\hline \multirow{4}{*}{ Summer and fall } & Lower bay & $5.44 \times 10^{8}$ & $68.9 \pm 3.5$ & $4.5 \times 10^{5} \pm 2.3 \times 10^{4}$ \\
\hline & Central bay & $3.40 \times 10^{8}$ & $53.6 \pm 2.7$ & $2.2 \times 10^{5} \pm 1.1 \times 10^{4}$ \\
\hline & West arm & $1.80 \times 10^{8}$ & $81.3 \pm 4.1$ & $1.8 \times 10^{5} \pm 8.8 \times 10^{3}$ \\
\hline & East arm & $9.00 \times 10^{7}$ & $70.3 \pm 3.5$ & $7.6 \times 10^{4} \pm 3.8 \times 10^{3}$ \\
\hline \multirow{4}{*}{ Fall and winter } & Lower bay & $5.44 \times 10^{8}$ & $-14.2 \pm 0.7$ & $-9.3 \times 10^{4} \pm 4.6 \times 10^{3}$ \\
\hline & Central bay & $3.40 \times 10^{8}$ & $-11.5 \pm 0.6$ & $-4.7 \times 10^{4} \pm 2.3 \times 10^{3}$ \\
\hline & West arm & $1.80 \times 10^{8}$ & $-1.3 \pm 0.1$ & $-2.7 \times 10^{3} \pm 135.7$ \\
\hline & East arm & $9.00 \times 10^{7}$ & $-0.5 \pm 0.0$ & $-515.7 \pm 25.8$ \\
\hline \multirow{4}{*}{ Winter and spring } & Lower bay & $5.44 \times 10^{8}$ & $17.6 \pm 0.9$ & $1.1 \times 10^{5} \pm 5.7 \times 10^{3}$ \\
\hline & Central bay & $3.40 \times 10^{8}$ & $-17.5 \pm 0.9$ & $-7.1 \times 10^{4} \pm 3.6 \times 10^{3}$ \\
\hline & West arm & $1.80 \times 10^{8}$ & $-26.6 \pm 1.3$ & $-5.7 \times 10^{4} \pm 2.9 \times 10^{3}$ \\
\hline & East arm & $9.00 \times 10^{7}$ & $-36.4 \pm 1.8$ & $-3.9 \times 10^{4} \pm 2.0 \times 10^{3}$ \\
\hline \multirow{4}{*}{ Spring and summer } & Lower bay & $5.44 \times 10^{8}$ & $19.4 \pm 1.0$ & $1.3 \times 10^{5} \pm 6.3 \times 10^{3}$ \\
\hline & Central bay & $3.40 \times 10^{8}$ & $17.2 \pm 0.9$ & $7.0 \times 10^{4} \pm 3.5 \times 10^{3}$ \\
\hline & West arm & $1.80 \times 10^{8}$ & $6.0 \pm 0.3$ & $1.3 \times 10^{4} \pm 652.1$ \\
\hline & East arm & $9.00 \times 10^{7}$ & $15.7 \pm 0.8$ & $1.7 \times 10^{4} \pm 846.9$ \\
\hline
\end{tabular}

Additionally, while glacial freshwater input has been shown to have some impact on NCP estimates in Greenland fjords, Meire et al. (2015) found biological processes to be the main driver of carbon dynamics. In a study similar to ours in Glacier Bay, Alaska, Meire and his team estimated air-sea $\mathrm{CO}_{2}$ fluxes and NCP in the Godthåbsfjord system in western Greenland, as well as the impact of freshwater on these estimates. They identified biological processes as the most important driver of carbon dynamics, accounting for 65 to $70 \%$ of the total $\mathrm{CO}_{2}$ uptake by the fjord system (Meire et al., 2015).

Some studies suggest that internal waves may form within the lower bay in an area of station 02, known as Sitakaday Narrows. This is an area of constriction with accelerated currents that can produce hydraulic instabilities, potentially causing internal waves that may influence mixing at depth as well as at a distance from this region (Hooge and Hooge, 2002). These internal waves may affect nutrient replenishment to surface waters, as well as mixing of DIC across the mixed layer. This addition of high-DIC waters from depth may also lead to an underestimation of NCP. However, we cannot make an estimation of how this affects our NCP estimations, as there is debate about how often internal waves form in Glacier Bay.

\section{Results}

\subsection{Spatial and seasonal salinity distributions}

Salinity distributions throughout the bay were generally the result of the influence of glacial runoff. During this summer season salinity ranged from 22.9 in surface waters at station 20 to 32.5 in the bottom waters of station 24 in Cross Sound. Isohalines were horizontal down to $\sim 50 \mathrm{~m}$ from the upper arms through the upper portion of the lower bay then became vertical in the lower bay, intersecting the surface just north of station 01 (Fig. 3).

Salinity was more constrained during the fall, with a full water column range between 25.3 in the surface waters at station 07 and 31.4 at depth $(\sim 130 \mathrm{~m})$ at station 13 . Similar to the previous summer, isohalines remained horizontal from the upper arms to the mid-lower bay near station 01, where they become vertical and intersected the surface. Salinities in the lower bay near were between $\sim 30$ and 31 , with the higher salinities at depth in Cross Sound.

During the winter salinity had a narrow range 29.6 and 31.6. The highest salinities were observed in the bottom waters at station 24 , though salinity was similar at all depth at this station $(\sim 31.4)$. The lowest salinities $(\sim 30)$ were within the top $10 \mathrm{~m}$ of station 12 with similar surface salinities throughout both arms. In the spring, salinity continued to have a narrow range, with bay-wide salinities between $\sim 28.9$ at the surface of station 12 and 31.7 in the bottom water of station 24. Salinities below a depth of $50 \mathrm{~m}$ were relatively homogeneous at $\sim 31$ (Fig. 3). 


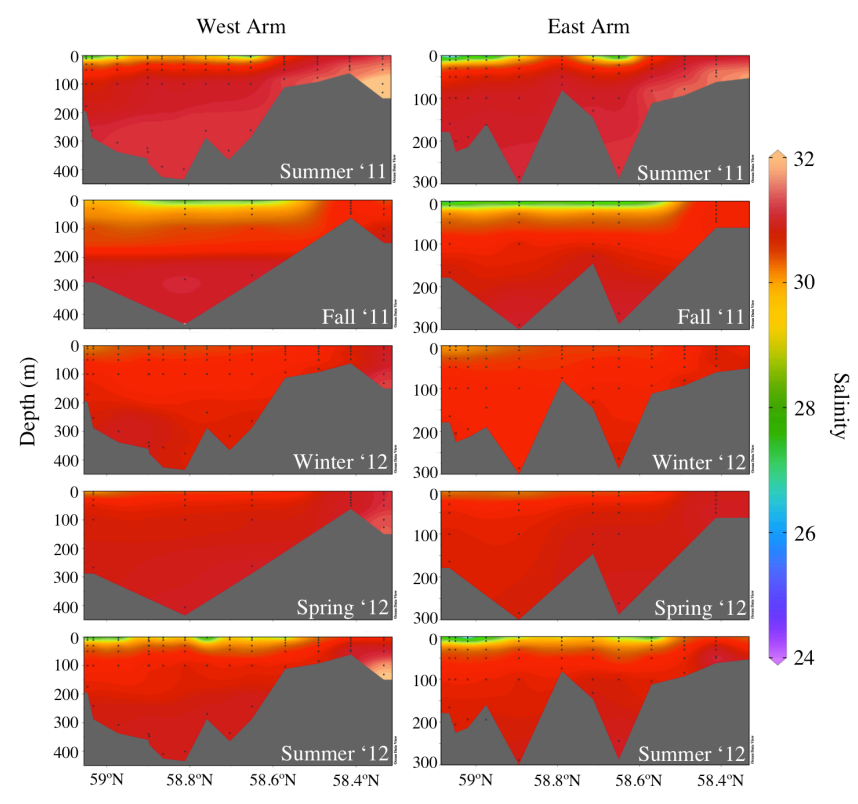

Figure 3. Spatial and seasonal distribution of salinity in the water column.

Returning to summer conditions in 2012, a strong salinity gradient was observed in the upper $50 \mathrm{~m}$ along the east and west arms. Salinities across the bay ranged from 24.1 in the surface waters of station 12 to 32.2 , at depth at station 24 . The lowest salinities were observed in the surface waters at the head of both arms, with this low-salinity signal stretching south through the central bay. Stations within the lower bay had the highest salinities having salinities between $\sim 31$ and 32 at all depths.

\subsection{Spatial and seasonal distributions of DIC and nitrate}

DIC and nitrate are important inorganic components that are consumed during photosynthesis at various rates throughout the year in Glacier Bay. DIC concentrations during the summer of 2011 ranged from $\sim 1400$ to $2100 \mu \mathrm{mol} \mathrm{kg}{ }^{-1}$, with the lowest concentrations in the arms and upper-central bay. Nitrate concentrations throughout the water column ranged from $\sim 2.5$ to $\sim 37 \mu \mathrm{mol} \mathrm{kg}{ }^{-1}$, with slightly less variability in the surface layer $\left(\sim 2.5\right.$ and $\left.24 \mu \mathrm{mol} \mathrm{kg}{ }^{-1}\right)$. Surface nitrate concentrations were low, but remained $>5 \mu \mathrm{mol} \mathrm{kg}^{-1}$ at all stations. While there was a large drawdown of nitrate, particularly in spring and summer (as much as $20 \mu \mathrm{mol} \mathrm{kg}^{-1}$ when compared to winter concentrations), surface waters were not depleted at any of the observed stations.

In the fall of 2011, DIC and nitrate concentrations increased in the surface waters, with DIC ranging from $\sim 1700$ to $2040 \mu \mathrm{mol} \mathrm{kg}^{-1}$, while concentrations reached $\sim 2075 \mu \mathrm{mol} \mathrm{kg}{ }^{-1}$ below the surface. Water column nitrate concentrations were between $\sim 12$ and $32 \mu \mathrm{mol} \mathrm{kg}{ }^{-1}$, with similar concentrations within surface waters (11 to

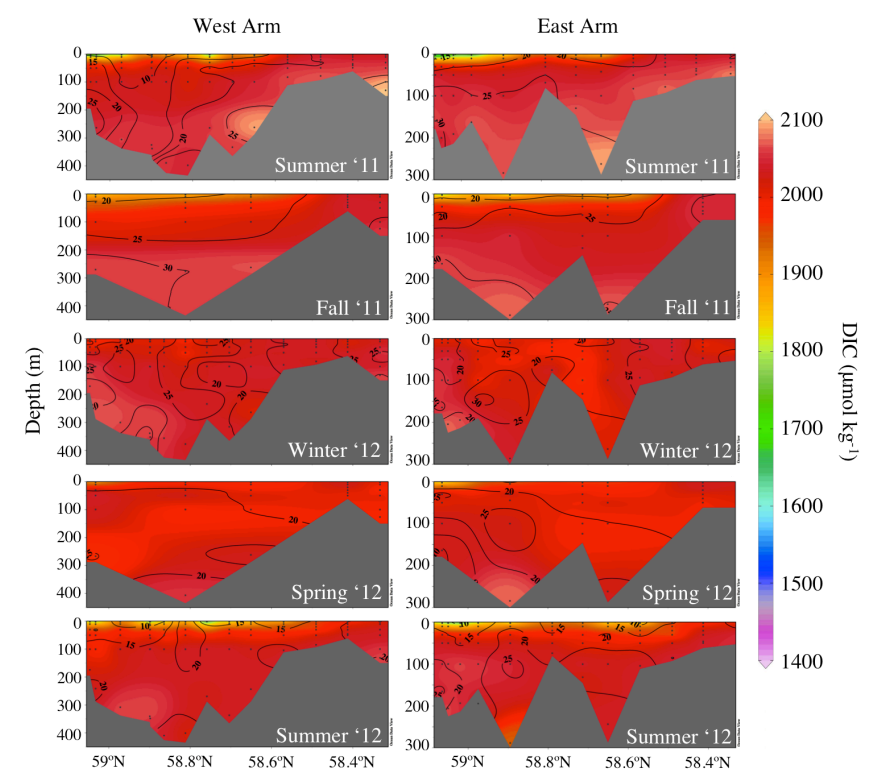

Figure 4. Spatial and seasonal distribution of DIC in the water column. Contours represent nitrate concentrations.

$30 \mu \mathrm{mol} \mathrm{kg}{ }^{-1}$ ) and the lowest concentrations observed in the arms. DIC concentrations were much more constrained during the winter $\left(\sim 1920\right.$ to $\left.2075 \mu \mathrm{mol} \mathrm{kg}{ }^{-1}\right)$ than during previous seasons. Nitrate concentrations ranged from $\sim 12$ to $33 \mu \mathrm{mol} \mathrm{kg}{ }^{-1}$.

During the spring of 2012, DIC and nitrate had reduced concentrations in surface waters across the bay. Surface DIC concentrations were between $\sim 1750$ and $2025 \mu \mathrm{mol} \mathrm{kg}{ }^{-1}$, with water column concentrations reaching $\sim 2075 \mu \mathrm{mol} \mathrm{kg}{ }^{-1}$ (Fig. 4). Nitrate concentrations ranged from $\sim 7$ to $\sim 31 \mu \mathrm{mol} \mathrm{kg}{ }^{-1}$, with an observed surface water maximum of $\sim 20 \mu \mathrm{mol} \mathrm{kg}{ }^{-1}$. Further drawdown of DIC and nitrate in surface waters was observed during the summer of 2012. However, concentrations did not drop as low as was observed during the previous summer. DIC concentrations ranged from $\sim 1545$ to $2066 \mu \mathrm{mol} \mathrm{kg} \mathrm{kg}^{-1}$. Nitrate concentrations varied from $\sim 13$ to $33 \mu \mathrm{mol} \mathrm{kg}{ }^{-1}$, with surface concentrations between $\sim 17$ and $31 \mu \mathrm{mol} \mathrm{kg}^{-1}$. The stations with the lowest DIC and nitrate concentrations were those within the east arm and west arm (Fig. 4).

\subsection{Rates and masses of NCP}

The seasonal transition between the summer and fall of 2011 had the largest rates of NCP observed during the year of study. Rates of NCP were positive in all regions of the bay and were highest within the east and west arms of the bay at $70.3 \pm 3.5$ and $81.3 \pm 4.1 \mathrm{mmol} \mathrm{C} \mathrm{m}^{-2} \mathrm{~d}^{-1}$, respectively. A similar NCP rate of $68.9 \pm 3.4 \mathrm{mmol} \mathrm{C} \mathrm{m}^{-2} \mathrm{~d}^{-1}$ was observed within the lower bay, while the central bay had the lowest rate between of $53.6 \pm 2.7 \mathrm{mmol} \mathrm{C} \mathrm{m}^{-2} \mathrm{~d}^{-1}$ (Table 1). 
Calculated rates of NCP became negative between fall and winter, as well as from winter to spring. Between fall and winter, the lower bay had a rate of $-14.2 \pm 0.7 \mathrm{mmol} \mathrm{Cm}^{-2} \mathrm{~d}^{-1}$ followed by the central bay at $-11.5 \pm 0.6 \mathrm{mmol} \mathrm{C} \mathrm{m}^{-2} \mathrm{~d}^{-1}$. Rates of $\mathrm{NCP}$ were negative in the east and west arms $(-0.5 \pm 0.03$ and $-1.3 \pm 0.1 \mathrm{mmol} \mathrm{C} \mathrm{m}^{-2} \mathrm{~d}^{-1}$, respectively). Between the winter and spring of 2012, rates of NCP remained negative within the east and west arms $(-36.4 \pm 1.8$ and $-26.6 \pm 1.3 \mathrm{mmol} \mathrm{C} \mathrm{m}^{-2} \mathrm{~d}^{-1}$, respectively), and to a lesser degree in central bay $\left(-17.5 \pm 0.9 \mathrm{mmol} \mathrm{C} \mathrm{m}^{-2} \mathrm{~d}^{-1}\right)$. Positive NCP rate was estimated for the lower bay of $17.6 \pm 0.9 \mathrm{mmol} \mathrm{C} \mathrm{m}^{-2} \mathrm{~d}^{-1}$. Between the spring and summer of 2012 NCP rates were positive across the bay, with the highest rate in lower bay $\left(19.4 \pm 1.0 \mathrm{mmol} \mathrm{C} \mathrm{m}^{-2} \mathrm{~d}^{-1}\right)$. The central bay and the east arm had rates of $17.2 \pm 0.9$ and $15.7 \pm 0.8 \mathrm{mmol} \mathrm{C} \mathrm{m}^{-2} \mathrm{~d}^{-1}$, respectively, while the west arm had a lower rate at $6.0 \pm 0.3 \mathrm{mmol} \mathrm{C} \mathrm{m}^{-2} \mathrm{~d}^{-1}$.

The total mass $\left(\mathrm{kg} \mathrm{Cd}^{-1}\right)$ of carbon produced from NCP was also estimated between each season (Table 1). Production occurred between the summer and fall of 2011, with the greatest production in the lower bay $\left(4.5 \times 10^{5} \pm 1.3 \times 10^{4} \mathrm{~kg} \mathrm{C} \mathrm{d}^{-1}\right)$. The central bay had a large amount of production $\left(2.2 \times 10^{5} \pm 1.1 \times 10^{4} \mathrm{~kg} \mathrm{C} \mathrm{d}^{-1}\right)$, followed by the west and east arms $\left(1.8 \times 10^{5} \pm 8.8 \times 10^{3}\right.$ and $7.6 \times 10^{4} \pm 3.8 \times 10^{3} \mathrm{~kg} \mathrm{C} \mathrm{d}^{-1}$, respectively).

Between the fall and winter the lower bay had carbon production of $-9.3 \times 10^{4} \pm 4.6 \times 10^{3} \mathrm{~kg} \mathrm{Cd}^{-1}$, while the east arm had a lowest degree of production at $-5.2 \times 10^{2} \pm 2.6 \mathrm{~kg} \mathrm{Cd}^{-1}$. NCP masses in central bay and west arm were also negative $\left(-4.7 \times 10^{4} \pm 2.3 \times 10^{4}\right.$ and $-2.7 \times 10^{3} \pm 1.4 \times 10^{2} \mathrm{~kg} \mathrm{Cd}^{-1}$, respectively). Between the winter and spring of 2012, masses in the east and west arms were estimated at $-3.9 \times 10^{4} \pm 2.0 \times 10^{3}$ and $-5.8 \times 10^{4} \pm 2.9 \times 10^{3} \mathrm{~kg} \mathrm{Cd}^{-1}$, respectively, while the central bay had a value of $-7.1 \times 10^{4} \pm 3.6 \times 10^{3} \mathrm{~kg} \mathrm{Cd}^{-1}$. The lower bay was the only region to have a positive NCP of $1.1 \times 10^{5} \pm 5.7 \times 10^{3} \mathrm{~kg} \mathrm{C} \mathrm{d}^{-1}$.

Transitioning from the spring to summer the lower bay had the greatest production $\left(1.3 \times 10^{5} \pm 6.3 \times 10^{3} \mathrm{~kg} \mathrm{Cd}^{-1}\right)$, followed by the central bay $\left(7.0 \times 10^{4} \pm 3.5 \times 10^{3} \mathrm{~kg} \mathrm{Cd}^{-1}\right)$. The arms exhibited the lowest biomass production, with an NCP in the west arm of $1.3 \times 10^{4} \pm 6.5 \times 10^{2}$ and $1.7 \times 10^{4} \pm 8.5 \times 10^{2} \mathrm{~kg} \mathrm{C} \mathrm{d}^{-1}$ in the east arm.

\subsection{Spatial and seasonal distribution of POC}

During the summer of 2011 surface POC concentrations were between $\sim 12$ and $\sim 55 \mu \mathrm{mol} \mathrm{kg}{ }^{-1}$. Station 20 had the highest POC concentration at all sampled depths $(\sim 46$, $\sim 30$, and $\sim 42 \mu \mathrm{mol} \mathrm{kg}^{-1}$, surface to bottom), while the west arm had the highest POC concentrations below the surface ( $\sim 33 \mu \mathrm{mol} \mathrm{kg} \mathrm{kg}^{-1}$ at $50 \mathrm{~m}$ and depth). The west and east arms exhibited negative AOU $\left(\sim-80\right.$ and $\sim-64 \mu \mathrm{mol} \mathrm{kg}^{-1}$, re-

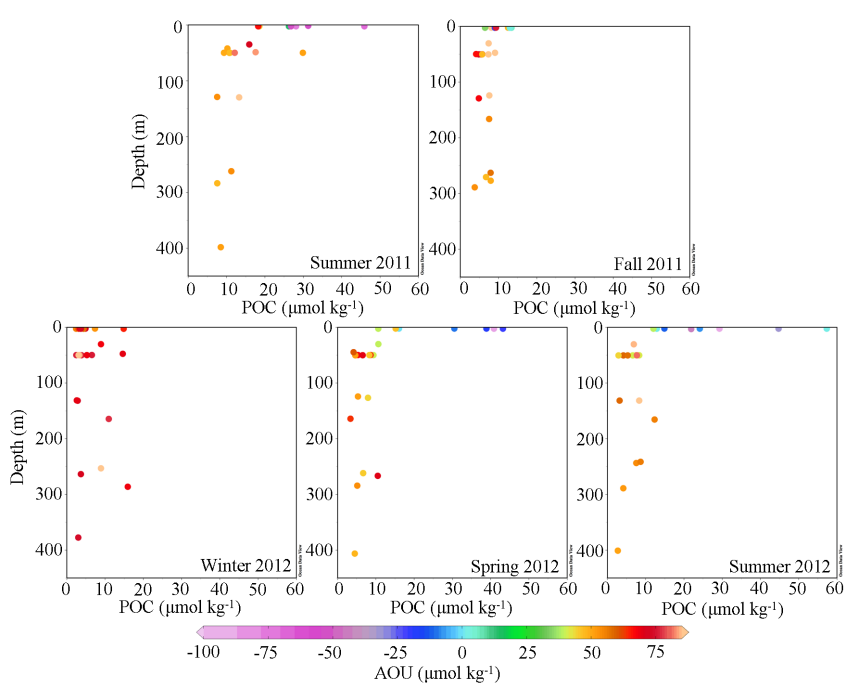

Figure 5. Seasonal scatter plots of POC concentrations vs. depth vs. AOU for each season between the summer of 2011 through the summer of 2012. Color bar represents AOU in $\mu \mathrm{mol} \mathrm{kg} \mathrm{kg}^{-1}$.

spectively). Below the surface concentrations were similar $\left(\sim 9 \mu \mathrm{mol} \mathrm{kg}{ }^{-1}\right)$, while surface waters had a POC concentration of $\sim 28 \mu \mathrm{mol} \mathrm{kg}-1$. Lower bay had relatively lower POC concentrations ( $\sim 15 \mu \mathrm{mol} \mathrm{kg}{ }^{-1}$ at all depths).

POC concentrations decreased, especially within surface waters during the fall. A maximum regional POC concentration $\left(\sim 13 \mu \mathrm{mol} \mathrm{kg}^{-1}\right)$ was observed in surface waters of the west arm. Below the surface layer POC concentrations were low, between $\sim 5$ and $\sim 8 \mu \mathrm{mol} \mathrm{kg}{ }^{-1}$. A maximum regional surface AOU $\left(\sim 82 \mu \mathrm{mol} \mathrm{kg}{ }^{-1}\right)$ was estimated for the lower bay and a minimum $\left(\sim 2 \mu \mathrm{mol} \mathrm{kg}{ }^{-1}\right)$ in the surface waters of the central bay (Fig. 5).

In the winter of 2012, surface water POC concentrations were not found to exceed $20 \mu \mathrm{mol} \mathrm{kg} \mathrm{kg}^{-1}$ and AOU across the bay was on the order of $\sim 70 \mu \mathrm{mol} \mathrm{kg} \mathrm{kg}^{-1}$. Surface POC concentrations ranged from $\sim 2$ to $\sim 15 \mu \mathrm{mol} \mathrm{kg}{ }^{-1}$, while POC concentrations at depth varied between $\sim 3$ and $16 \mu \mathrm{mol} \mathrm{kg}^{-1}$. The regional maximum in POC was in the surface waters in the west arm $\left(\sim 11 \mu \mathrm{mol} \mathrm{kg}^{-1}\right)$. The east arm and lower bay both had maximum POC concentrations in the bottom waters ( $\sim 14$ and $\sim 9 \mu \mathrm{mol} \mathrm{kg}^{-1}$, respectively).

POC concentration in the surface waters increased during the spring of 2012, primarily within northern regions of the bay. The east arm had the greatest increase in surface POC $\left(\sim 62 \mu \mathrm{mol} \mathrm{kg}^{-1}\right)$, with concentrations decreasing in the surface water to the south. The west arm and central bay had similar surface POC concentrations of $\sim 35$ and $\sim 30 \mu \mathrm{mol} \mathrm{kg}^{-1}$, respectively. The lower bay had the lowest surface POC concentrations, with $\sim 13 \mu \mathrm{mol} \mathrm{kg}^{-1}$, while having the highest rate of NCP and AOU $(\sim 93 \mu \mathrm{mol} \mathrm{kg}-1)$. The lower bay subsurface and deepwater AOU values were positive and POC concentrations, $\sim 9 \mu \mathrm{mol} \mathrm{kg}^{-1}$ each, were the highest among the regions. 
AOU values decreased in surface waters across the bay, while rates of NCP were elevated within these waters during the summer of 2012. Surface POC concentrations were highest in the east arm $\left(\sim 50 \mu \mathrm{mol} \mathrm{kg}^{-1}\right)$, while POC concentrations decreased below the surface layer, ranging from $\sim 4.5$ to $\sim 7 \mu \mathrm{mol} \mathrm{kg}{ }^{-1}$ at $50 \mathrm{~m}$ and $\sim 5$ to $\sim 8 \mu \mathrm{mol} \mathrm{kg}{ }^{-1}$ at depth. The west arm and central bay regions had surface POC concentrations of $\sim 23 \mu \mathrm{mol} \mathrm{kg}^{-1}$ and the lower bay exhibited the lowest surface POC concentration with $\sim 13 \mu \mathrm{mol} \mathrm{kg}^{-1}$.

\subsection{Relationship between DIC and oxygen}

During the summer of 2011, oxygen concentrations ranged from $\sim 190$ to $\sim 400 \mu \mathrm{mol} \mathrm{kg}{ }^{-1}$. All samples below the surface layer, as well as surface samples within the lower bay followed the Redfield ratio, with concentrations at depth between $\sim 190$ and $280 \mu \mathrm{mol} \mathrm{kg}^{-1}$ (Fig. 6). Surface samples of stations within the arms and central bay had high oxygen concentrations and low DIC. Surface oxygen was higher than that at depth, ranging between $\sim 230$ and $400 \mu \mathrm{mol} \mathrm{kg}{ }^{-1}$. However, in the lower bay DIC concentrations remained elevated $\left(\sim 2030 \mu \mathrm{mol} \mathrm{kg}^{-1}\right)$ and oxygen concentrations were low $\left(\sim 240 \mu \mathrm{mol} \mathrm{kg}{ }^{-1}\right)$. During the fall, surface samples within the arms and central bay continued to deviate from Redfield. Surface oxygen concentrations ranged from $\sim 210$ to $\sim 330 \mu \mathrm{mol} \mathrm{kg}^{-1}$ and corresponded with reduced surface DIC concentrations. At depth, oxygen concentrations varied between $\sim 200$ and $280 \mu \mathrm{mol} \mathrm{kg}{ }^{-1}$ with $\mathrm{C}: \mathrm{O}$ ratios close to Redfield.

All samples, at the surface and at depth, followed Redfield closely with surface waters having slightly higher oxygen and lower DIC concentrations than those at depth during the winter of 2012. Surface water oxygen concentrations were between 250 and $\sim 280 \mu \mathrm{mol} \mathrm{kg}^{-1}$, while deeper waters ranged from $\sim 230$ to $255 \mu \mathrm{mol} \mathrm{kg} \mathrm{kg}^{-1}$.

In the spring, DIC was drawn down and oxygen concentrations increased, having a range between $\sim 270$ and $410 \mu \mathrm{mol} \mathrm{kg}^{-1}$. Oxygen concentrations were amplified, while DIC was reduced at stations in the northernmost regions of both arms. These samples deviated the most from Redfield, while the remaining samples adhered to the Redfield ratio. Below the surface layer, oxygen concentration throughout the bay ranged from $\sim 250$ to $280 \mu \mathrm{mol} \mathrm{kg}^{-1}$.

During the summer of 2012, the surface waters within the two arms and central bay continued to diverge from Redfield. DIC concentrations within the more northern regions of the bay (east arm, west arm, and central bay) were increasingly drawn down, while oxygen concentrations remained elevated. Surface oxygen concentrations ranged from $\sim 260$ to $\sim 410 \mu \mathrm{mol} \mathrm{kg}{ }^{-1}$, with lower oxygen concentrations at depth, varying from 200 to $\sim 270 \mu \mathrm{mol} \mathrm{kg}{ }^{-1}$.

\subsection{Air-sea gas flux}

During the summer of 2011 winds were relatively low, at $\sim 1.6 \mathrm{~m} \mathrm{~s}^{-1}$, with surface waters of the central bay and the west arm were undersaturated with respect to atmospheric $\mathrm{CO}_{2}$ with $p \mathrm{CO}_{2}$ values of $\sim 250 \mu \mathrm{atm}$. The central bay and the west arm acted as minor sinks ( $\sim-0.3 \pm 0.02 \mathrm{mmol} \mathrm{C} \mathrm{m}^{-2} \mathrm{~d}^{-1}$ each). The lower bay and east arm had much higher seawater $p \mathrm{CO}_{2}$ values of $\sim 488$ and $\sim 463 \mu \mathrm{atm}$ and acted as sources for atmospheric $\mathrm{CO}_{2}$ of $\sim 0.2 \pm 0.01 \mathrm{mmol} \mathrm{C} \mathrm{m}^{-2} \mathrm{~d}^{-1}$ for each region (Fig. 7).

During the fall of 2011, winds increased slightly to $\sim 2.0 \mathrm{~m} \mathrm{~s}^{-1}$ and surface waters in all regions of the bay were oversaturated with respect to the atmospheric $\mathrm{CO}_{2}$. The lower bay experienced the highest $p \mathrm{CO}_{2}$, at $\sim 670 \mu$ atm, and acted as the largest source for atmospheric $\mathrm{CO}_{2}$ with a flux of $\sim 1.1 \pm 0.06 \mathrm{mmol} \mathrm{C} \mathrm{m}^{-2} \mathrm{~d}^{-1}$. The central bay also had elevated $p \mathrm{CO}_{2}$ with $\sim 510 \mu \mathrm{atm}$, leading to outgassing of $\sim 0.5 \pm 0.03 \mathrm{mmol} \mathrm{C} \mathrm{m}^{-2} \mathrm{~d}^{-1}$. The east arm had a $p \mathrm{CO}_{2}$ and flux values similar to that of the central bay $\left(p \mathrm{CO}_{2}=\sim 514 \mu \mathrm{atm}\right.$; flux $=\sim 0.5 \mathrm{mmol} \pm 0.03$ $\mathrm{C} \mathrm{m}^{-2} \mathrm{~d}^{-1}$ ). Air-sea $\mathrm{CO}_{2}$ flux in the west arm was $\sim 0.3 \pm 0.02 \mathrm{mmol} \mathrm{C} \mathrm{m}^{-2} \mathrm{~d}^{-1}$, similar to the east arm and central bay, but had a slightly lower $p \mathrm{CO}_{2}$ of $\sim 482 \mu \mathrm{atm}$ (Fig. 7).

Surface waters during the winter of 2012 were oversaturated in $\mathrm{CO}_{2}$ with respect to the atmosphere, and all regions experienced outgassing, with average wind speeds of $\sim 2.1 \mathrm{~m} \mathrm{~s}^{-1}$. Regional $p \mathrm{CO}_{2}$ values were more constrained, especially within the arms and central bay, ranging from $\sim 400 \mu \mathrm{atm}$ in the west arm and central bay to $\sim 432 \mu \mathrm{atm}$ in the east arm. Similar $p \mathrm{CO}_{2}$ values and seawater temperatures $\left(\sim 3.5^{\circ} \mathrm{C}\right)$ led the west arm and central bay to experience comparable $\mathrm{CO}_{2}$ fluxes of $\sim 0.03 \pm 0.002$ and $0.06 \pm 0.003 \mathrm{mmol} \mathrm{Cm}^{-2} \mathrm{~d}^{-1}$. The east arm had a slightly higher surface temperature $\left(\sim 4.1^{\circ} \mathrm{C}\right)$ and flux, with $\sim 0.18 \pm 0.01 \mathrm{mmol} \mathrm{C} \mathrm{m}^{-2} \mathrm{~d}^{-1}$, while the lower bay had a slightly higher $\mathrm{CO}_{2}$ flux of $\sim 0.76 \pm 0.04 \mathrm{mmol} \mathrm{C} \mathrm{m}^{-2} \mathrm{~d}^{-1}$.

In the spring, seawater temperatures increased slightly to $\sim 5^{\circ} \mathrm{C}$ across the bay, while salinity remained similar to winter values $(\sim 29$ to 31$)$. However, all regions except for the lower bay transitioned to sinks for atmospheric $\mathrm{CO}_{2} . p \mathrm{CO}_{2}$ in the lower bay remained oversaturated with respect to $\mathrm{CO}_{2}$ at $\sim 423 \mu \mathrm{atm}$ and had a flux of $\sim 0.11 \pm 0.01 \mathrm{mmol} \mathrm{C} \mathrm{m}^{-2} \mathrm{~d}^{-1}$. Within the other three regions of the bay, surface water temperatures increased by just over $1{ }^{\circ} \mathrm{C}$. However, $p \mathrm{CO}_{2}$ decreased in the surface waters, and these regions acted as sinks for atmospheric $\mathrm{CO}_{2}$. The east arm had the greatest decrease in $p \mathrm{CO}_{2}$, dropping from $\sim 432$ to $\sim 167 \mu$ atm and exhibiting seasonal outgassing of $\sim-0.87 \pm 0.04 \mathrm{mmol} \mathrm{C} \mathrm{m}^{-2} \mathrm{~d}^{-1}$. The central bay and west arm regions were also seasonal sinks for $\mathrm{CO}_{2}$, taking up $\sim-0.39 \pm 0.02$ in the central bay and $\sim-0.60 \pm 0.03 \mathrm{mmol} \mathrm{C} \mathrm{m}^{-2} \mathrm{~d}^{-1}$ in the west arm. 


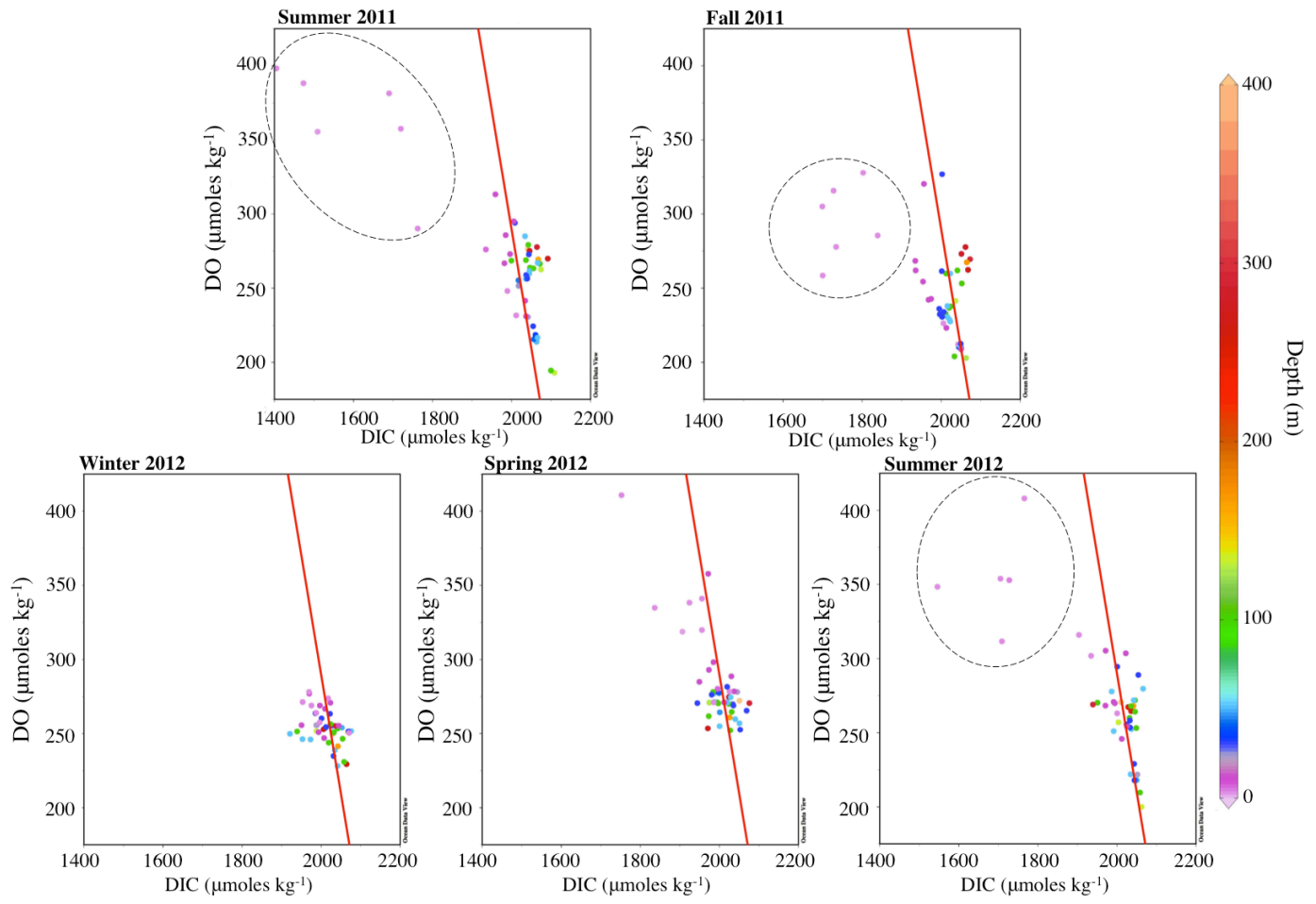

Figure 6. Scatter plots of DIC concentrations vs. oxygen concentrations vs. depth for each season between the summer of 2011 and the summer of 2012. Color bar represents depth in meters. The red line depicts the C: O Redfield ratio of 106: -170 . Dashed circles highlight samples that deviate from Redfield.

During the summer of 2012, $p \mathrm{CO}_{2}$ in the east arm increased to $\sim 337 \mu \mathrm{atm}$, with $\sim-0.13 \pm 0.01 \mathrm{mmol} \mathrm{C} \mathrm{m}^{-2} \mathrm{~d}^{-1}$ of ingassing. The central bay had a $p \mathrm{CO}_{2}$ of $\sim 200 \mu$ atm and a flux of $\sim-0.44 \pm 0.02 \mathrm{mmol} \mathrm{C} \mathrm{m}^{-2} \mathrm{~d}^{-1}$. The lower bay and west arm acted as sources for atmospheric $\mathrm{CO}_{2}$, having $p \mathrm{CO}_{2}$ values of $\sim 411$ and $\sim 507 \mu \mathrm{atm}$, respectively, while the lower bay experienced a near-neutral flux of $\sim 0.04 \pm 0.002 \mathrm{mmol} \mathrm{C} \mathrm{m}^{-2} \mathrm{~d}^{-1}$. The west arm was oversaturated with respect to atmospheric $\mathrm{CO}_{2}$ with a $p \mathrm{CO}_{2}$ of $\sim 507 \mu \mathrm{atm}$ and a flux of $\sim 0.26 \pm 0.01 \mathrm{mmol} \mathrm{C} \mathrm{m}^{-2} \mathrm{~d}^{-1}$.

\section{Discussion}

\subsection{Relationships of DIC, nitrate, and dissolved oxygen}

During the summer of 2011, surface waters in the arms and upper-central bay deviated from Redfield ratios for $\mathrm{C}: \mathrm{O}$ and $\mathrm{C}: \mathrm{N}$ (Figs. 6 and 8 ) Waters below this surface layer followed the Redfield ratios. Nitrate and phosphate concentrations in the surface waters were not observed to reach depletion during the summer, indicating that they were being continuously supplied to the surface layer and that phosphate (data not shown) was not limiting. Sustained nutrient concentrations and nutrient replenishment may be the result of physical in- teractions within the bay, including wind, tidal and internal wave mixing, and mixing across sills.

Increases in oxygen and the reduction in macronutrient concentrations, including DIC, within the more northern arms of the bay were due to primary production coupled with the influence of glacier runoff and salinity-driven stratification limiting mixing and nutrient replenishment in the mixed layer. In the fall of 2011, DIC and nitrate concentrations increased, while oxygen decreased in the surface waters as primary production slowed and wind mixing increased. Due to decreasing primary production, nutrient concentrations were similar within surface waters, with the lowest concentrations observed in the arms where glacial runoff was still impacting surface waters. Surface water ratios for $\mathrm{C}: \mathrm{O}$ and $\mathrm{C}: \mathrm{N}$ deviated from the Redfield ratios, but less so than observed during summer as primary production began to decrease during the fall (Figs. 6 and 8). During the winter of 2012, increased wind mixing and the reduction of glacial input led to deeper water column mixing, with much more constrained DIC and nitrate concentrations. During the winter, nitrate and DIC concentrations continued to increase, with $\mathrm{C}: \mathrm{O}$ and $\mathrm{C}: \mathrm{N}$ Redfield ratios indicating a decrease in primary production and increase in mixing (Figs. 6 and 8). While DIC and nitrate concentrations fell near the Redfield ratio, they deviated slightly from Redfield at the highest nitrate concentrations (Fig. 4). This may have been due to nitrification of 


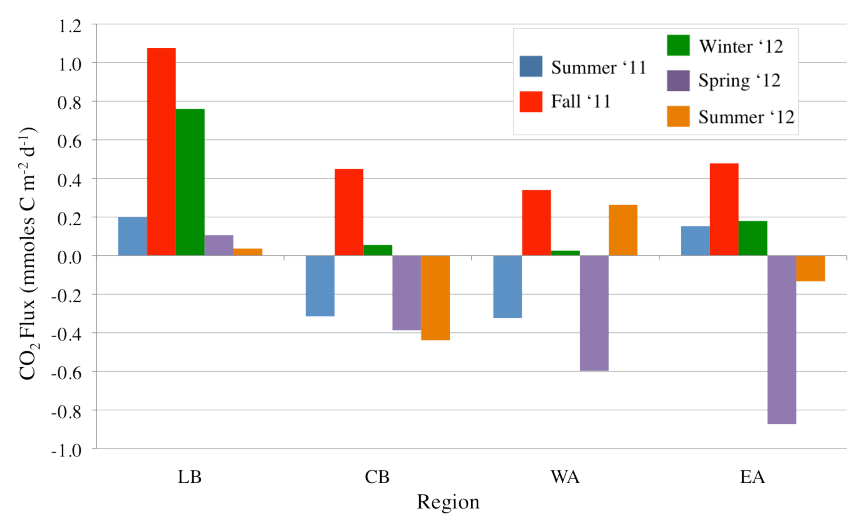

Figure 7. Seasonal air-sea $\mathrm{CO}_{2}$ fluxes by region in mmol $\mathrm{Cm}^{-2} \mathrm{~d}^{-1}$. Blue: summer of 2011; red: fall of 2011; green: winter of 2012; purple: spring of 2012, yellow $=$ summer of 2012.

ammonium by bacteria leading to an increase the nitrate concentration. Another possibility is "carbon overconsumption", the process in which more DIC is taken up than that inferred from the C: N Redfield ratio (Voss et al., 2011). Explanations for carbon overconsumption include the preferential remineralization of organic nitrogen (Thomas and Schneider, 1999) or an increased release of dissolved organic carbon (Engel, et al., 2002; Schartau et al., 2007).

As temperatures began to warm in the spring of 2012, the onset of glacial melt and primary production reduced DIC and nitrate, while increasing oxygen concentrations in surface waters across the bay. DIC and nitrate correlated closely with the Redfield ratio except for two surface samples located at the northernmost ends of each arm (Fig. 8). This deviation may be explained by the fact that these stations were the first to be influenced by glacial runoff during the onset of the glacial melt season.

Further reduction in DIC and nitrate concentrations in surface waters was observed during the summer of 2012 as primary production intensified, increasing oxygen concentrations. Low-nutrient glacial runoff was highest at this time of year, affecting surface water DIC and nitrate concentrations within the arms. However, concentrations did not drop as low as was observed during the previous summer. Macronutrients did not reach depletion during the summer of 2012, implying they were not the limiting primary productivity, possibly due to nutrient replenishment via tidal pumping. Surface nitrate concentration continued to deviate from the $\mathrm{C}: \mathrm{N}$ Redfield ratio as these macronutrients were increasingly drawn down by primary productivity and diluted by glacier runoff (Fig. 8). Surface waters in several regions also deviated from the $\mathrm{C}: \mathrm{O}$ Redfield ratio (Fig. 6), and those most affected were within the east arm and west arm, as well as upper central bay, where freshwater influence was greatest. Mixing of nutrient-rich marine waters from the Gulf of Alaska likely offset much of the drawdown from primary production and allowed these surface waters within the lower bay to fall closer to the Redfield ratio.

\subsection{NCP}

The seasonal transition between the summer and fall of 2011 had the largest rates of NCP observed during the year of study. During this time all NCP rates were positive, signifying enhanced primary productivity in the mixed layer. Rates of NCP became negative during the seasonal transitions from fall to winter, as well as from winter to spring. These negative NCP values indicate that air-sea fluxes (discussed in Sect. 5.6) and organic matter respiration were prominent, increasing $\mathrm{CO}_{2}$ (DIC) concentrations in the surface waters and overwhelming any weaker signal from primary production. Between the fall and winter, the lower bay experienced the highest degree of $\mathrm{CO}_{2}$ flux when compared to biological production. The biological production was overwhelmed by $\mathrm{CO}_{2}$ influx in the east and west arms, but to a lesser degree than in regions to the south.

Between the winter and spring of 2012 the lower bay was the only region where biological production dominated the $\mathrm{CO}_{2}$ flux with a positive NCP rate, reflecting the region's nutrient-rich marine influence from the Gulf of Alaska. The $\mathrm{CO}_{2}$ flux signal exceeded NCP within the east and west arms of the bay and, to a lesser extent, the central bay. In the transition from spring to summer in 2012, primary production was evident in the NCP rates. The west arm experienced a lower rate of NCP, possibly the result of the strong lowmacronutrient glacial influences along the arm, which may work to hinder production. Additionally, large volumes of glacial flour imparted into the surface waters from runoff during summer may have limited the photic depth and thus impeded some productivity in the upper arms of the bay.

The total mass of carbon produced between seasons via NCP was also estimated (Table 1). Between the summer and fall of 2011, we observed the greatest production of organic carbon of any seasonal transition, with the largest production signal in the lower bay and decreasing to the north as glacial influence increased. Elevated production estimates within the lower could be due to continued nutrient replenishment to surface waters as a result of mixing with the more marine waters outside of the bay.

Despite all regions of the bay being dominated by airsea $\mathrm{CO}_{2}$ flux during the fall and winter seasons (Table 1), there was a substantial contrast in magnitudes of estimates between the marine-dominated lower bay and the glacially influenced east arm. These differences in magnitude were likely the result of a higher degree of wind and tidal mixing at stations outside of and near the mouth of the bay, allowing this region to have elevated air-sea flux when compared to the east and west arms (Fig. 7).

The production signal within the arms and central regions of the bay continued to be overwhelmed by air-sea flux between the winter and spring of 2012 (Table 1). While pro- 

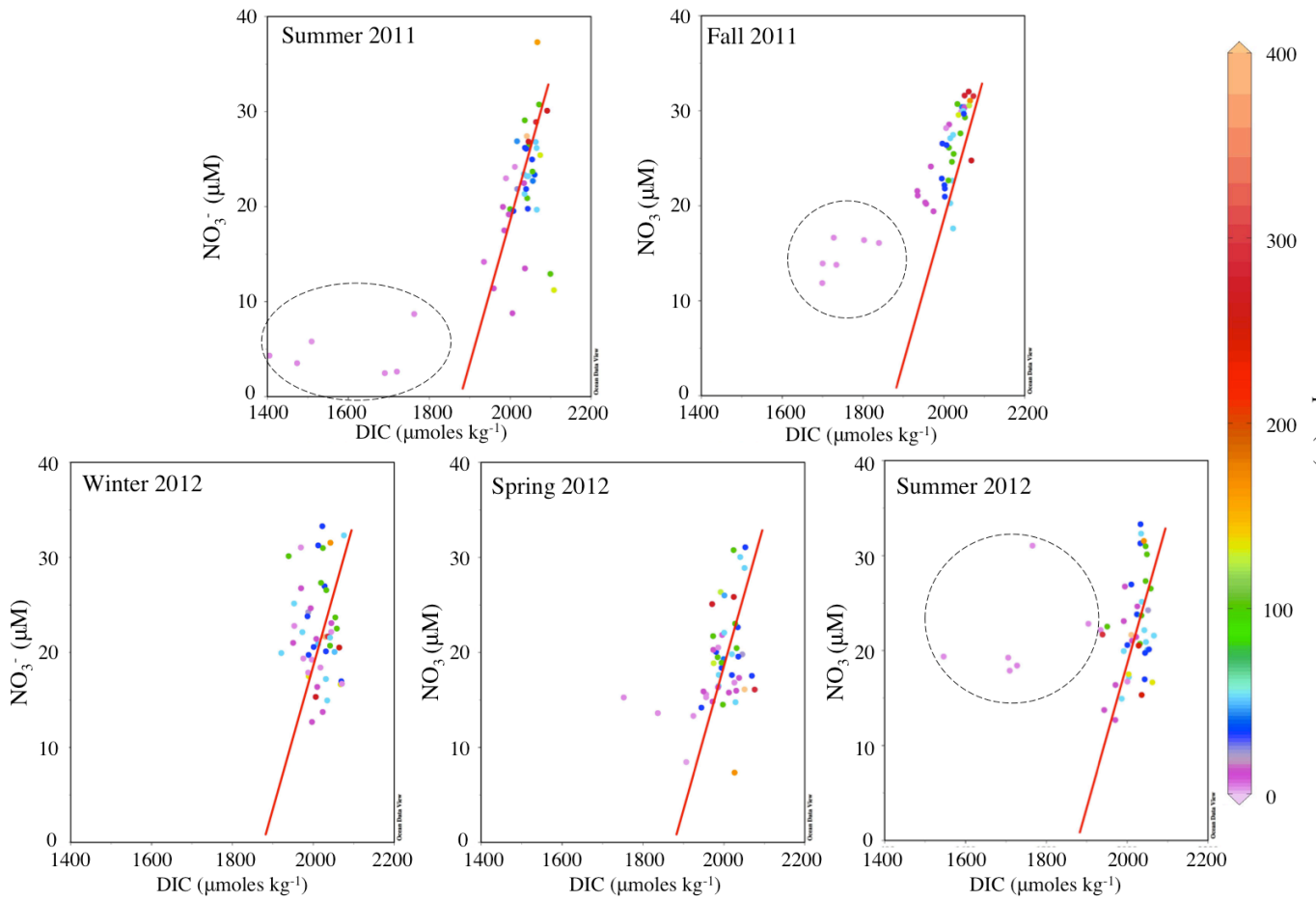

Figure 8. Scatter plots of DIC concentrations vs. $\mathrm{NO}_{3}^{-}$concentrations vs. depth for each season between the summer of 2011 and the summer of 2012. Color bar represents depth in $\mathrm{m}$. The red line depicts the $\mathrm{C}: \mathrm{N}$ Redfield ratio of $106: 16$. Dashed circles highlight samples that deviate from Redfield.

duction estimates remained negative in the northern regions of the bay, the lower bay had a positive NCP mass signifying increased primary production and a decrease in air-sea flux in this region. This increase in NCP in the lower bay may have been the result of earlier nutrient replenishment via the more marine waters outside of the bay. Between the spring and summer there was increased production across the bay as stratification strengthen and the hours of daylight increased, with the largest production estimates in the lower bay. The east and west arms exhibited the lowest biomass production, likely hindered by the inundation of low-nutrient glacial runoff that formed a fresh surface layer and imparted glacial flour into the surface waters in these regions.

\subsection{Air-sea flux}

Aside from primary production, air-sea carbon dioxide $\left(\mathrm{CO}_{2}\right)$ flux also impacts carbon concentrations within surface waters. In Glacier Bay, air-sea fluxes varied regionally and seasonally between the summer of 2011 and the summer of 2012. During the summer of 2011, winds were relatively low, reducing turbulent mixing, allowing for stratification and thus primary production. Surface waters in the lower bay and east arm acted as sources for atmospheric $\mathrm{CO}_{2}$, while the central bay and the west arm acted as sinks (Fig. 7). Drawdown of $\mathrm{CO}_{2}$ in the west arm may be attributed to primary production, as well as the influx of low nutrient glacial melt.
The central bay has been noted to have elevated production levels (Hooge and Hooge, 2002) that may account for the drawdown of DIC and the region's sink status. Within the east arm, seawater temperatures were high, increasing the $p \mathrm{CO}_{2}$ of these waters and, combined with influence of the reduced alkalinity concentrations, resulting in an oversaturation of $\mathrm{CO}_{2}$ in the seawater with respect to the atmosphere, overwhelming any effect from DIC drawdown via primary production and making this region a source for atmospheric $\mathrm{CO}_{2}$. Turbulent mixing across and outside the sill, as well as through Sitakaday Narrows, likely reduced stratification and enhanced air-sea flux, causing this region to be a source for atmospheric $\mathrm{CO}_{2}$.

In the fall of 2011, winds increased slightly and all surface waters across the bay experienced oversaturation with respect to the atmospheric $\mathrm{CO}_{2}$, with the lower bay acting as the strongest regional source (Fig. 7). The high $p \mathrm{CO}_{2}$ values observed during fall, despite strong DIC drawdown during summer, may be the result of a variety of interactions. Reduced glacial runoff during fall increased alkalinity concentrations (Reisdorph and Mathis, 2014) and surface water temperatures declined, allowing them to hold more $\mathrm{CO}_{2}$ while mixing brought DIC-rich waters from depth to the surface. Increased winds also likely led to enhanced turbulent mixing across the bay.

During the winter of 2012, surface waters across all regions of the bay continued to experience outgassing (Fig. 7), 
though to a lesser degree than during fall. The lower bay experienced the largest degree of outgassing, likely due to its more turbulent mixing than other regions. Despite winter having the lowest seawater temperatures, wind mixing peaked and likely allowed for $\mathrm{CO}_{2}$-rich waters from depth and the air to enter the surface waters, increasing $p \mathrm{CO}_{2}$ in all regions of the bay.

Several regions of Glacier Bay transitioned to sinks for atmospheric $\mathrm{CO}_{2}$ during the spring of 2012 as primary production increased and winds slowed. The lower bay was the exception, remaining oversaturated with respect to $\mathrm{CO}_{2}$ and continuing to act as a minor source for atmospheric $\mathrm{CO}_{2}$. In the more northern regions, surface waters experienced a slight increase in surface temperatures, but due to the onset of spring productivity DIC was drawn down in the surface waters, decreasing the $p \mathrm{CO}_{2}$ and allowing them to become sinks for atmospheric $\mathrm{CO}_{2}$. The east arm experienced the largest decrease in $p \mathrm{CO}_{2}$ and became the largest sink region within the bay, while the west arm and central bay underwent similar flux transitions as primary production increased, drawing down DIC in the surface waters. Within the arms, the onset of glacial melt may have aided in setting up stratification, also helping to lead to larger sink statuses within these regions.

During the summer of 2012, waters in the northern regions became increasingly saturated with respect to atmospheric $\mathrm{CO}_{2}$. While $p \mathrm{CO}_{2}$ in the east arm did increase from spring values, perhaps due to a small increase in surface water temperatures and reductions in alkalinity from glacial runoff, it was still undersaturated with respect to atmospheric $p \mathrm{CO}_{2}$. Atmospheric $\mathrm{CO}_{2}$ uptake within the central bay strengthened slightly from spring as $p \mathrm{CO}_{2}$ in this region decreased, likely due to high levels of primary production in this region, as well as high nutrient replenishment from tidal mixing between the waters of lower bay and the stratified waters within the central bay (Hooge and Hooge, 2002). Conversely, the lower bay remained a minimal source for atmospheric $\mathrm{CO}_{2}$, while the west arm transitioned into source during the summer. The lower bay experiences the highest degree of turbulent or tidal mixing across the sill, within Cross Sounds, and through Sitakaday Narrows, inhibiting stratification and primary production and causing this region to act as a source for atmospheric $\mathrm{CO}_{2}$ year-round. The difference in the sink/source status of the east and west arms of the bay was likely the result of differences in glacial influences, with the west arm more influenced by low-alkalinity glacial runoff as it has the majority of the tidewater glaciers along its length. These glaciers caused a higher degree of alkalinity and DIC dilution than was observed within the west arm.

\section{Conclusions}

Glacier Bay experiences a high degree of spatial and temporal throughout the year. Environmental influences vary seasonally along a gradient from the glacially influenced northern regions within the arms to the marine-influenced lower bay. This imparts spatial differences in stratification and macronutrient availability that affect biological processes and thus rates of NCP. Despite Glacier Bay's limited exchange with the marine waters of the Gulf of Alaska, it has been observed to support elevated primary production through most of the year (Hooge and Hooge, 2002). However, rapid deglaciation within Glacier Bay has imparted a high volume of fresh glacial runoff, a portion of which has been from tidewater glaciers that melt directly into the bay, affecting stratification and macronutrient concentrations and influencing air-sea $\mathrm{CO}_{2}$ exchange and NCP. For this study, we calculated rates of $\mathrm{NCP}$ and air-sea $\mathrm{CO}_{2}$ exchange in each of the four regions of Glacier Bay in order to assess current production levels in the bay and how these processes may impact the carbon dynamics. To date, there are no NCP or air-sea flux estimates for Glacier Bay or similar southeastern Alaska fjords, despite playing an important role in the global carbon cycle.

Rates of NCP were positive across the bay between the summer and fall of 2011, as well as between the spring and summer of 2012 during peak times of primary production. $\mathrm{NCP}$ was highest during the transition between summer and fall of 2011, with regional NCP rates ranging from $\sim 54$ to $\sim 80 \mathrm{mmol} \mathrm{C} \mathrm{m}^{-2} \mathrm{~d}^{-1}$. Rates during the summer of 2012 were lower, between $\sim 6$ and $\sim 20 \mathrm{mmol} \mathrm{C} \mathrm{m}^{-2} \mathrm{~d}^{-1}$.

Between the fall of 2011 and winter of 2012, as well as between the winter and spring of 2012, air-sea gas exchange overwhelmed any production signal across the bay, especially during the fall (Fig. 7; Table 1). The one exception was the lower bay between winter and spring, where NCP rates were positive, likely due to earlier replenishment of nutrients from marine waters outside the bay.

The impact of rapid deglaciation in Glacier Bay can be observed in the seasonal impacts on the carbon cycling and NCP in this estuarine system. This study enhances the limited biogeochemical literature regarding Glacier Bay and includes one of the more robust data sets from Glacier Bay. We found the highest level of NCP to occur between the summer and fall seasons in 2011, with the greatest production within the glacially influenced arms of the bay. The influence of the surrounding glaciers has the potential to significantly impact the efficiency and makeup of the marine food web within Glacier Bay in unknown ways with unknown consequences. However, additional study of these influences and their effects on the rate of NCP is needed to fully understand the impacts of future deglaciation. 
Acknowledgements. Thanks to the National Park Service for supporting this work through grant number G7224 to the University of Alaska Fairbanks. We would also like to thank Lewis Sharman, Natalie Monacci, Kristen Shake, Seth Danielson, and the entire NPS staff in Gustavus and Juneau, Alaska, for their help in sample collection, logistics, and editing. We also want to thank the staff and visitors to Glacier Bay National Park and Preserve, as well as the community of Gustavus for their support and interest in this project.

Edited by: S. Pantoja

\section{References}

Aracena, C., Lange, C. B., Luis Iriarte, J., Rebolledo, L., and Pantoja, S.: Latitudinal patterns of export production recorded in surface sediments of the Chilean Patagonian fjords $\left(41-55^{\circ} \mathrm{S}\right)$ as a response to water column productivity, Cont. Shelf Res., 31, 340-355, doi:10.1016/j.csr.2010.08.008, 2011.

Bates, N. R., Best, M. H. P., and Hansell, D. A.: Spatio-temporal distribution of dissolved inorganic carbon and net community production in the Chukchi and Beaufort Seas, Deep-Sea Res. Pt. II, 52, 3303-3323, doi:10.1016/j.dsr2.2005.10.005, 2005.

Cross, J. N., Mathis, J. T., and Bates, N. R.: Hydrographic controls on net community production and total organic carbon distributions in the eastern Bering Sea, Deep-Sea Res. Pt. II, 65-70, 98109. doi:10.1016/j.dsr2.2012.02.003, 2012.

Dickson, A. G. and Millero, F. J.: A comparison of the equilibrium constants for the dissociation of carbonic acid in seawater media, Deep-Sea Res., 34, 1733-1743, doi:10.1016/01980149(87)90021-5, 1987.

Engel, A., Goldthwait, S., Passow, U., and Alldredge, A.: Temporal decoupling of carbon and nitrogen dynamics in a mesocosm diatom bloom, Limnol. Oceanogr., 47, 753-761, doi:10.4319/lo.2002.47.3.0753, 2002.

Goñi, M. A., Teixeira, M. J., and Perkey, D. W.: Sources and distribution of organic matter in a river-dominated estuary (Winyah Bay, SC, USA), Estuar. Coast. Shelf Sci., 57, 1023-104, doi:10.1016/S0272-7714(03)00008-8, 2003.

Hill, S. J., Ciavola, L., Etherington, M. J., and Klaar, D. F.: Estimation of freshwater runoff into Glacier Bay, Alaska and incorporation into a tidal circulation model, Estuar. Coast. Shelf Sci., 82, 95-107, 2009.

Hood, E., Fellman, J., Spencer, R. G. M., Hernes, P. J., Edwards, R., D'Amore, D., and Scott, D.: Glaciers as a source of ancient and labile organic matter to the marine environment, Nature, 426, 1044-1048, 2009.

Hood, E., Battin, T., Fellman, J., O’Neel, S., and Spencer, R. G. M.: Storage and release of organic carbon from glaciers and ice sheets, Nat. Geosci., 8, 91-96, 2015.

Hooge, E. R. and Hooge, P. N.: Fjord oceanographic processes in Glacier Bay, Alaska, Glacier Bay Report, Gustavus, AK., 1-144, 2002.

Hooge, P. N., Hooge, E. R., Solomon, E. K., Dezan, C. L., Dick, C .A., Mondragon, J., Reiden, H. S., and Etherington, L. L.: Fjord oceanography monitoring handbook: Glacier Bay, Alaska, U.S Geol. Surv., 1-75, 2003.

Langdon, C.: Determination of dissolved oxygen in seawater by Winkler titration using the amperometric technique, GO-SHIP
Repeat Hydrogr. Manual: A Collection of Expert Reports \& Guidelines, 14, 1-18, 2010.

Lee, K.: Global net community production estimated from the annual cycle of surface water total dissolved inorganic carbon, Limnol. Oceanogr., 46, 1287-1297, doi:10.4319/lo.2001.46.6.1287, 2001.

Lewis, E. and Wallace D. W. R.: CO2SYS - program developed for $\mathrm{CO}_{2}$ system calculations, Report ORNL/CDIAC-105 (Carbon Dioxide Information and Analysis Centre), Oak Ridge National Lab., U.S. Department of Energy, 1998.

Mathis, J. T. and Questel, J. M.: The impacts of primary production and respiration on the marine carbonate system in the Western Arctic: implications for $\mathrm{CO}_{2}$ fluxes and ocean acidification, Cont. Shelf Res., 67, 42-51, doi:10.1016/j.csr.2013.04.041, 2013.

Mathis, J. T., Bates, N. R., Hansell, D. A., and Babila, T.: Net community production in the northeastern Chukchi Sea, DeepSea Res. Pt. II, 56, 1213-1222, doi:10.1016/j.dsr2.2008.10.017, 2009.

Mehrbach, C., Culberson, C. H., Hawley, J. E., and Pytkowicz, R. M.: Measurement of the apparent dissociation constants of carbonic acid in seawater at atmospheric pressure, Limnol. Oceanogr., 18, 897-907, 1973.

Meire, L., Søgaard, D. H., Mortensen, J., Meysman, F. J. R., Soetaert, K., Arendt, K. E., Juul-Pedersen, T., Blicher, M. E., and Rysgaard, S.: Glacial meltwater and primary production are drivers of strong $\mathrm{CO}_{2}$ uptake in fjord and coastal waters adjacent to the Greenland Ice Sheet, Biogeosciences, 12, 2347-2363, doi:10.5194/bg-12-2347-2015, 2015.

Millero, F. J., Feistel, R., Wright, D. G., and McDougall, T. J.: The composition of Standard Seawater and the definition of the Reference-Composition Salinity Scale, Deep-Sea Res. Pt. I, 55, 50-72, doi:10.1016/j.dsr.2007.10.001, 2008.

Mordy, C. W., Eisner, L. B., Proctor, P., Stabeno, P., Devol, A. H., Shull, D. H., Napp, J. M., and Whitledge, T.: Temporary uncoupling of the marine nitrogen cycle: accumulation of nitrite on the Bering Sea shelf, Mar. Chem., 121, 157-166, doi:10.1016/j.marchem.2010.04.004, 2010.

Reisdorph, S. C. and Mathis, J. T.: The dynamic controls on carbonate mineral saturation states and ocean acidification in a glacially dominated estuary, Estuar. Coast. Shelf Sci., 144, 8-18, 2014.

Schartau, M., Engel, A., Schröter, J., Thoms, S., Völker, C., and Wolf-Gladrow, D.: Modelling carbon overconsumption and the formation of extracellular particulate organic carbon, Biogeosciences, 4, 433-454, doi:10.5194/bg-4-433-2007, 2007.

Schlitzer, R.: Ocean Data View, http://odv.awi.de (last access: 31 July 2015), 2013.

Thomas, H. and Schneider, B.: The seasonal cycle of carbon dioxide in Baltic Sea surface waters, J. Mar. Syst., 22, 53-67, 1999.

Uppström, L. R.: The boron/chlorinity ratio of deep-sea water from the Pacific Ocean, Deep-Sea Res., 21, 161-162, doi:10.1016/0011-7471(74)90074-6, 1974.

Voss, M., Baker, A., Bange, H. W., Conley, D., Cornell, S., Deutsch, B., Engel, A., Ganeshram, R., Garnier, J., Heiskanen, A. S., Jickells, T., Lancelot, C., Mcquatters-Gollop, A., Middelburg, J., Schiedek, D., Slomp, C. P., and Conley, D. P.: Nitrogen processes in coastal and marine ecosystems, in: The European Nitrogen Assessment, edited by: Sutton, M. A., Howard, C. M., Erisman, J. W., Billen, G., Bleeker, A., Grennfelt, P., van Grinsven, H., 
Grizzetti, B., Cambridge University Press, New York, 147-176, 2011.

Wanninkhof, R. and McGillis, W. R. A cubic relationship between air-sea $\mathrm{CO}_{2}$ exchange and wind speed, Geoph, 26, 1889-1892, 1999.
Williams, P. J.: On the definition of plankton production terms, edited by: Li, W. K. W. and Maestrini, S. Y., Measurements of primary production from the molecular to the global scale, ICES Mar. Sci. Symp., 197, 9-1., 1993. 